\title{
Prevalence of Truancy and Its Associated Factors among School-Going Malaysian Adolescents: Data from Global School-Based Health Survey 2012
}

\author{
Norzawati Yoep ${ }^{1}$, Leni Tupang², Ahmad Nadzri Jai' ${ }^{1}$, Lim Kuang Kuay ${ }^{1}$, Faizah Paiwai ${ }^{1}$, \\ Noor Safiza Mohd Nor ${ }^{1}$ \\ ${ }^{1}$ Institute for Public Health, Ministry of Health, Kuala Lumpur, Malaysia \\ ${ }^{2}$ Keningau Division Health District, Sabah, Malaysia \\ Email: "norzawati@moh.gov.my
}

Received 15 March 2016; accepted 11 July 2016; published 14 July 2016

Copyright (C 2016 by authors and Scientific Research Publishing Inc.

This work is licensed under the Creative Commons Attribution International License (CC BY).

http://creativecommons.org/licenses/by/4.0/

(c) (i) Open Access

\section{Abstract}

This study aimed to examine the prevalence of truancy and its associated factors among school going Malaysian adolescents. The Malaysia Global School-based Health Survey (GSHS) was conducted from February to April 2012 involving 28,933 students aged 12 - 17 years old. A two-stage cluster sampling was used to select the schools and students with an overall response rate of $88.6 \%$. The data were obtained using the GSHS questionnaire. The prevalence of truancy was $30.8 \%$ and significantly higher among male than female ( $32.9 \%$ vs $28.7 \%)$. The factors associated with truancy were current smoker (aOR: 2.23; 95\% CI: 2.03 - 2.46), current drug user (aOR: 2.23; 95\% CI: 1.52 - 3.29), current alcohol use (aOR: 1.39; 95\% CI: 1.24 - 1.56), having been bullied (aOR: 1.31; 95\% CI: 1.22 - 1.42) and not currently live with both parents (aOR: 1.25; 95\% CI: 1.16 - 1.35). High truancy among school going adolescents warrants a new effective strategy to control truancy in Malaysia.

\section{Keywords}

Adolescent, GSHS, Protective Factors, Risk Factors, Truancy

\section{Introduction}

Truancy, defined as habitual engagement in unexcused absence from school is a type of behavior displayed by

"Corresponding author.

How to cite this paper: Yoep, N., Tupang, L., Jai, A. N., Kuay, L. K., Paiwai, F., \& Nor, N. S. M. (2016). Prevalence of Truancy and Its Associated Factors among School-Going Malaysian Adolescents: Data from Global School-Based Health Survey 2012. Psychology, 7, 1053-1060. http://dx.doi.org/10.4236/psych.2016.78106 
students that has drawn the concerns of parents, educators and society (Zhang et al., 2010). Truancy among adolescents is a serious problem around the world, and is associated with various negative health and socioeconomical outcomes (Vaughn et al., 2013; Carli et al., 2013). Studies have shown that the behavior is on the rise and crimes committed by these adolescents are alarming (Shah et al., 2012).

Truancy has been strongly linked to greater discipline problems in school and is a stepping stone for delinquent criminal behaviour in adulthood (Nik Jaafar et al., 2013). A myriad of negative outcomes have been found to be associated with truancy from school including social isolation, mood and conduct disorders, sleep disturbances and longer term outcomes such as dropping out from school (Muula et al., 2012). Truant students are also at higher risk of being drawn into behavior involving drug, alcohol and violence (Garry, 1996).

In Malaysia, truancy has been labelled as one of the major problems in this country. Despite efforts by schools, communities, states, and the federal government to reduce truancy over the past two decades, there is little evidence that any positive impact has been made on school attendance (Ministry of Education Malaysia, 1995). According to the Ministry of Education records, in 2010, out of 111,484 discipline problem cases, 19,545 (17.5\%) cases involved truancy. In 2011, from the 108,650 discipline problem cases, 18,550 (17\%) involved truanting behavior (Ishak \& Fin, 2013). Studies carried out in Malaysia on various social problems involving teenagers, have reported a truancy percentage among students of around 30\% (Shah et al., 2012; Hidayah et al., 2003; Nik Ruzyanei et al., 2009).

The causes of truancy may vary from individual to individual and need to be understood before determining the most effective means of controlling truancy. Although research in this area is increasing, most findings are from small scale studies, which are not representative of the Malaysian adolescents. This paper aims to determine the nationwide prevalence of truancy among adolescents aged 12 - 17 years in Malaysia and its associated factors.

\section{Method}

\subsection{Participants}

Participants for this study were respondents from Malaysian Global School-based Student Health Survey (GSHS) 2012. Two stage cluster sampling was used to select a representative sample of school going adolescents aged 12 - 17 years old in Malaysia. Only students with parental/guardian consent were allowed to participate in the study. Students without consent were regarded as non-response. Detailed description on the methodology was discussed elsewhere (Fadhli et al., 2014).

\subsection{Procedure}

Self-administered questionnaire developed for the Global School-based Health Survey by the World Health Organization (WHO) was used. This was validated by a panel of experts in Malaysia. The dependent variable, truancy, was evaluated by the question "During the past 30 days, on how many days did you miss classes or school without permission?”. Those who responded 0 day was classified as Non-truancy whilst respondents who answered 1 or more days were classified as Truancy. The independent variables examined in this study were Parental or guardians supervision, which was assessed by "Did your parents/guardians know what you were doing with your free time" and the Peer support was measured by the question "How many close friend/s that you have". The response options were "Yes" or "No".

Other factors that were investigated in the study were smoking status, alcohol consumption, drug use and having been bullied in the past 30 days. Those who reported smoking/drinking/drug usage at least once in the past 30 days were classified as "Current smoker", “Current alcohol drinker” and "Current drug user”, whilst those reported they had been bullied at least once in the past 30 days was classified as "Currently bullied”.

\subsection{Data Analysis}

SPSS version 21 (SPSS IBM, New York, U.S.A) was used to perform the statistical analysis. The outcome variable was Truancy. Data were weighted taken into the consideration the study design and non-response rate before the analysis. Descriptive statistics were used to describe the population characteristic and estimate the prevalence of truancy. Multivariable logistic regression using backward likelihood method was used to determine associations between the effect of each independent variables (peer support, parental/guardian supervision, 
smoking, alcohol use, drug use and being bullied) and truancy within the last 30 days after controlling for the effects of other independents variables. All statistical analysis were analysed at 95\% Confidence Interval.

\section{Results}

The overall response rate for the GSHS was $88.6 \%$ of which 25,461 (88.0\%) responded to the module on truancy. The proportions of male and female adolescents were almost equal; ( $50.2 \%$ males and $49.8 \%$ females). More than half of the adolescents were of Malay descent (60.8\%), followed by Chinese descent (20.2\%), Indian descent (6.9\%), Sarawak and Sabah descent (4.9\%) and others (1.7\%). This is comparable to the Malaysian adolescent population as a whole. About two third of the respondents were from lower secondary (63.0\% aged 12 - 15 years old) (Table 1).

Table 2 shows that the prevalence of truancy was significantly higher among males students $(32.9 \%$ vs $28.7 \%$ ), students from upper secondary ( $35.8 \%$ vs $27.9 \%$ ), and from single parent background ( $36.0 \%$ vs $29.9 \%$ ). In particular, the prevalence of truancy among adolescents who reported smoking (50.0\% vs $28.3 \%$ ) and using drug (61.8\% vs $30.4 \%$ ) in the past 30 days was about double that of the respective comparison group.

Consistent with the differences in prevalence rates, multivariate logistic analysis revealed that current smokers (aOR: 2.23; 95\% CI: 2.03 - 2.46) and current drug users (aOR: 2.23; 95\% CI: 1.52 - 3.29) were more than twice as likely to be truant. Worthy of note, compared to the youngest age ( $\leq 13$ years old), the likelihood of truancy increase progressively with age up to 16 years old.

\section{Table 1. Distribution of school going adolescents by socio-demographic characteristics.}

\begin{tabular}{|c|c|c|c|c|c|c|c|c|c|c|}
\hline \multirow{3}{*}{ Factor } & \multicolumn{5}{|c|}{ Male } & \multicolumn{5}{|c|}{ Female } \\
\hline & \multirow{2}{*}{$\mathrm{N}$} & \multirow{2}{*}{$\mathrm{n}$} & \multirow{2}{*}{$\%$} & \multicolumn{2}{|c|}{$95 \%$ CI } & \multirow{2}{*}{$\mathrm{N}$} & \multirow{2}{*}{$\mathrm{n}$} & \multirow{2}{*}{$\%$} & \multicolumn{2}{|c|}{$95 \%$ CI } \\
\hline & & & & Lower & Upper & & & & Lower & Upper \\
\hline \multicolumn{11}{|c|}{ Age } \\
\hline$\leq 13$ year old & 231624 & 2793 & 20.6 & 18.7 & 22.6 & 243969 & 2588 & 21.8 & 19.8 & 23.9 \\
\hline 14 years old & 232912 & 2743 & 20.7 & 18.3 & 23.3 & 228473 & 2605 & 20.4 & 18.1 & 23.0 \\
\hline 15 years old & 223669 & 2796 & 19.9 & 18.2 & 21.6 & 229756 & 2752 & 20.5 & 18.6 & 22.6 \\
\hline 16 years old & 219518 & 2181 & 19.5 & 17.5 & 21.7 & 212116 & 2375 & 19.0 & 16.6 & 21.5 \\
\hline 17 years old & 217897 & 2210 & 19.4 & 17.4 & 21.5 & 204378 & 2407 & 18.3 & 16.0 & 20.8 \\
\hline \multicolumn{11}{|c|}{ Form } \\
\hline $\begin{array}{l}\text { Lower secondary } \\
\text { (12 - } 15 \text { years old) }\end{array}$ & 692041 & 8367 & 61.6 & 59.6 & 63.6 & 704025 & 7962 & 63.0 & 61.0 & 64.9 \\
\hline $\begin{array}{l}\text { Upper secondary } \\
\text { (16 - } 17 \text { years old) }\end{array}$ & 430599 & 4332 & 38.4 & 36.4 & 40.4 & 413801 & 4749 & 37.0 & 35.1 & 39.0 \\
\hline \multicolumn{11}{|c|}{ Ethnicity } \\
\hline Malay & 682231 & 8525 & 60.7 & 55.8 & 65.4 & 681512 & 8537 & 61.0 & 56.8 & 65.0 \\
\hline Chinese & 236792 & 2365 & 21.1 & 16.9 & 26.0 & 216502 & 2138 & 19.4 & 16.0 & 23.2 \\
\hline Indian & 76348 & 703 & 6.8 & 5.1 & 9.0 & 77604 & 737 & 6.9 & 5.7 & 8.4 \\
\hline Bumiputera Sabah & 52496 & 464 & 4.7 & 4.0 & 5.4 & 58151 & 527 & 5.2 & 4.2 & 6.4 \\
\hline Bumiputera Sarawak & 57622 & 448 & 5.1 & 4.2 & 6.3 & 64420 & 572 & 5.8 & 4.5 & 7.4 \\
\hline Others & 18892 & 203 & 1.7 & 1.2 & 2.3 & 19680 & 205 & 1.8 & 1.1 & 2.8 \\
\hline \multicolumn{11}{|c|}{ Parents marital status } \\
\hline Married and living together & 965082 & 10926 & 86.0 & 85.0 & 86.9 & 935920 & 10708 & 83.8 & 82.6 & 84.9 \\
\hline Single parents & 157576 & 1761 & 14.0 & 13.1 & 15.0 & 181052 & 1995 & 16.2 & 15.1 & 17.4 \\
\hline
\end{tabular}


Table 2. Prevalence of truancy among school-going adolescents by selected background variables.

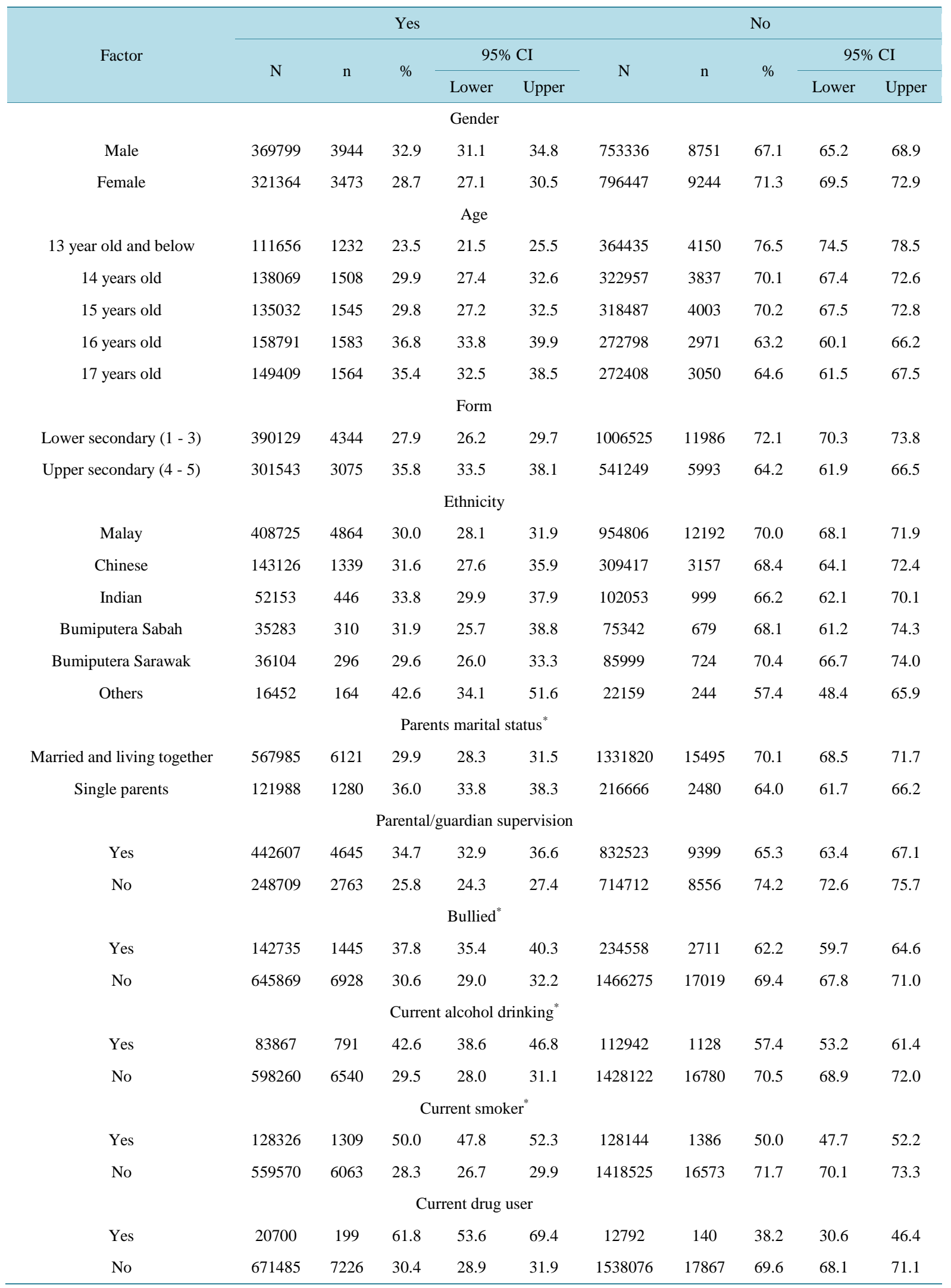


It then declined slightly for those 17 years (aOR: 1.59; 95\% CI: 1.45 - 1.75) although the risk was still higher than the reference age group. Finally, those who reported being bullied in the last 30 days had a slightly higher risk as well (aOR: 1.31; 95\% CI: 1.22 - 1.42). On the other hand, students having close friends (aOR: .84\%; 95\% CI: .71 - .99) and those who reported to have parental or guardian supervision (aOR: .70\%; 95\% CI: .66 - .75) were significantly less likely to be truant (Table 3).

Table 3. Multivariable regression analysis on factors associated with truancy among school going adolescents in Malaysia.

\begin{tabular}{|c|c|c|c|}
\hline \multirow{2}{*}{ Factors } & \multirow{2}{*}{ Adjusted OR } & \multicolumn{2}{|c|}{$95 \%$ CI } \\
\hline & & Lower & Upper \\
\hline Male & 1 & & \\
\hline Female & .99 & .93 & 1.06 \\
\hline 13 year old and below & 1 & & \\
\hline 14 years old & 1.25 & 1.13 & 1.37 \\
\hline 15 years old & 1.29 & 1.17 & 1.41 \\
\hline 16 years old & 1.76 & 1.60 & 1.94 \\
\hline 17 years old & 1.59 & 1.45 & 1.75 \\
\hline Malay & 1 & & \\
\hline Chinese & 1.00 & .92 & 1.09 \\
\hline Indian & 1.13 & .99 & 1.28 \\
\hline Bumiputera Sabah/Sarawak & .93 & .83 & 1.04 \\
\hline Others & 1.50 & 1.20 & 1.88 \\
\hline Married and living together & 1 & & \\
\hline Single parents & 1.25 & 1.16 & 1.35 \\
\hline Yes & .84 & .71 & .99 \\
\hline No & 1 & & \\
\hline Yes & .70 & .66 & .75 \\
\hline No & 1 & & \\
\hline Yes & 1.31 & 1.22 & 1.42 \\
\hline No & 1 & & \\
\hline Yes & 1.39 & 1.24 & 1.56 \\
\hline No & 1 & & \\
\hline Yes & 2.23 & 2.03 & 2.46 \\
\hline No & 1 & & \\
\hline Yes & 2.23 & 1.52 & 3.29 \\
\hline No & 1 & & \\
\hline
\end{tabular}




\section{Discussion}

Truancy prevalence and its related factors in Malaysia were examined in the nationwide Global School-based Health Survey. This study showed that the prevalence of truancy among school going adolescents was $30.8 \%$. This figure is comparable with other previous studies done in Malaysia (Shah et al., 2012; Hidayah et al., 2003) as well as GSHS data from neighbouring Indonesia, where it was reported at 32.0\% in 2007 (WHO, 2007 ). However, it is much higher compared to GSHS data from Thailand (18.2\%) in 2008 (WHO, 2008) and Swaziland in 2007 (Seter et al., 2007)_but considerably lower than Zambia (58.8\%) (Muula et al., 2012).

In term of risk factors, current smoking and drug use were identified as behaviors highly associated with truancy; specifically, twice the risk. Current alcohol use was also associated with a higher risk of truancy. Although the direction of the relationship cannot be established in the present study, this finding is consistent with Mounteney et al. (2010) who reported that truancy increases the level of alcohol use and alcohol-related problems.

Controlling for all other factors, another significant risk factor emerging from this study was the role of bullying in schools. Students who reported being victims of bullying were more likely to have been truant (aOR: 1.31; 95\% CI: 1.22 - 1.42). This supports GSHS findings from Thailand (Pengpid \& Peltzer, 2013), Swaziland (Seter et al., 2007) as well as Zambia (Muula et al., 2012). Absenteeism from school is possibly to avoid further victimization or assault. It is thus important that parents and school authorities explore the reasons behind truancy. Therefore, we believe schools should have a strict "anti-bullying” programme in-line with the Ministry of Education Malaysia’s Guidelines on Prevention and Handling of Bullying Behaviour Among Student in Malaysia (Ministry of Education Malaysia, 2010).

We observed that 13 years olds were less likely to be truant compared to older students. This is probably because younger adolescents are more likely to be supervised by their parents/guardians than older students (Choon et al., 2013).

Parent's marital status was another important finding in this study, specifically adolescents who reported that they have parents who live together were less likely to be truant than those with single parents. This is similar to the study on psycho-behavioural factors contributing to truancy among at-risk secondary school students in Kuala Lumpur, Malaysia (Shah et al., 2012). The study found that students with single parents were almost twice more likely to be involved in truancy.

Within the home environment, adolescents who reported their parents/guardians are aware of their activities were at lower risk of being truant. This protective effect was also seen in other studies on truancy (Muula et al., 2012; Seter et al., 2007). Our findings also extends previous research by Choon et al., 2013 on the parental attachment, peer attachment, and delinquency among adolescents. The study of adolescents aged 13 - 17 years old in four urban secondary schools found that father and mother attachments have negative relationships with adolescents' delinquency, including truancy. Parents who are more attached to their children are more aware of their children's daily activities and their friends.

In contrast to other studies, sex and ethnicity were not significantly associated with truancy. This supports the study based in at-risk secondary schools in metropolitan Kuala Lumpur (Nik Jaafar et al., 2013) as well as another study in a small urban area close to Kuala Lumpur (Shah et al., 2012). However, a study in the United States found that truancy is associated with ethnicity (Vaughn et al., 2013).

Truancy reduction programmes should aim at addressing a broad range of factors at different levels (Dembo \& Gulledge, 2009). For example, providing mentoring teacher-student relationships to encourage both attendance and performance at school through daily student check-ins and one-on-one interactions with teachers (DeSocio et al., 2007). Check and Connect, a school-based intervention program designed to engage students in school and support regular attendance, has been implemented in various elementary, middle, and high schools in both urban and suburban settings in the United States (Lehr et al., 2004). In addition to truancy programs at schools, there are community-based truancy interventions, for example, the Community Brigade Program, a community-based intervention designed to reduce truancy (Ministry of Education Malaysia, 1995).

\section{Conclusion}

Our study found a 30.8\% prevalence of school truancy within the past 30 days among adolescents in Malaysia. Factors such as current smoker, current drug user, current alcohol use, recent history of being bullied, and current parental marital status, which have been reported elsewhere, were identified as factors associated with truancy, and were also identified in our study. 


\section{Limitations}

In any study, it is important to recognize the limitations. Firstly the study was based on data collected by selfreports. Students may have misreported intentionally. One needs to be cautious about the validity of the responses of the questionnaire as it is entirely based on anonymity or due to under reporting. This was probably an advantage as well over named responses especially for sensitive questions on risk behaviors. Data were also collected from students who were available in schools on the day of the survey. Thus, students who were absent, both truant and otherwise were not included, hence we may have under estimated the prevalence of truancy.

\section{Human Subjects Approval Statement}

The study was approved by the Medical Research Ethics Committee, Ministry of Health, Malaysia and Ethics Committee, Ministry of Education, Malaysia.

\section{Acknowledgements}

The authors would like to thank Director General Health of Health Malaysia for his permission to publish this study.

\section{References}

Carli, V., Wasserman, C., Sarchiapone, M., Hoven, C., \& Wasserman, D. (2013). Working in Europe to Stop Truancy among Youth (WE-STAY). European Psychiatry, 28, 1. http://dx.doi.org/10.1016/S0924-9338(13)76671-9

Choon, L. J., Hasbullah, M., Ahmad, S., \& Ling, W. S. (2013). Parental Attachment, Peer Attachment, and Delinquency among Adolescents in Selangor, Malaysia. Asian Social Science, 9.

Dembo, R., \& Gulledge, L. M. (2009). Truancy Intervention Programs: Challenges and Innovations to Implementation. Criminal Justice Policy Review, 20, 437-456. http://dx.doi.org/10.1177/0887403408327923

DeSocio, J., VanCura, M., Nelson, L. A., Hewitt, G., Kitzman, H., \& Cole, R. (2007). Engaging Truant Adolescents: Results from a Multifaceted Intervention Pilot. Preventing School Failure: Alternative Education for Children and Youth, 51, 3-9. http://dx.doi.org/10.3200/PSFL.51.3.3-11

Fadhli, Y., Riyanti, S., Balkish, M. N. et al. (2014). Methodology of the National School-Based Health Survey in Malaysia, 2012. Asia Pacific Journal of Public Health, 26.

Garry, E. M. (1996). Truancy: First Step to a Lifetime of Problems. Juvenile Justice Bulletin.

Hidayah, N., Hanafiah, M., Idris, M., Rosnah, S., Ibrahim, N., \& Nonnah, C. (2003). Risk Behavior amongst Adolescents of a Rural Land Development Scheme in Peninsular Malaysia. Jurnal Kesihatan Masyarakat, 9, 12-16.

Ishak, Z., \& Fin, L. S. (2013). Truants’ and Teachers’ Behaviors in the Classroom. Procedia-Social and Behavioral Sciences, 103, 1228-1237. http://dx.doi.org/10.1016/j.sbspro.2013.10.451

Lehr, C. A., Sinclair, M. F., \& Christenson, S. L. (2004). Addressing Student Engagement and Truancy Prevention during the Elementary School Years: A Replication Study of the Check \& Connect Model. Journal of Education for Students Placed at Risk, 9, 279-301. http://dx.doi.org/10.1207/s15327671espr0903 4

Ministry of Education Malaysia (1995). Surat Pekeliling Ikhtisas Bil. 6/1995: Mengangani Masalah Ponteng di Sekolah.

Ministry of Education Malaysia (2010). Surat Pekeliling Ikhtisas Bilangan 8 tahun 2010: Garis Panduan Pencegahan dan Menangani Perbuatan Buli Dalam Kalangan Murid di Sekolah.

Mounteney, J., Haugland, S., \& Skutle, A. (2010). Truancy, Alcohol Use and Alcohol-Related Problems in Secondary School Pupils in Norway. Health Education Research, 25, 945-954. http://dx.doi.org/10.1093/her/cyq044

Muula, A. S., Rudatsikira, E., Babaniyi, O., Songolo, P., \& Siziya, S. (2012). Prevalence and Correlates for School Truancy among Pupils in Grades 7-10: Results from the 2004 Zambia Global School-Based Health Survey. BMC Research Notes, 5, 48. http://dx.doi.org/10.1186/1756-0500-5-48

Nik Jaafar, N. R., Tuti Iryani, M. D., Wan Salwina, W. I. et al. (2013). Externalizing and Internalizing Syndromes in Relation to School Truancy among Adolescents in High-Risk Urban Schools. Asia-Pacific Psychiatry, Suppl. 1, 27-34. http://dx.doi.org/10.1111/appy.12072

Nik Ruzyanei, N. J., Wan Salwina, W. I., Tuti Iryani, M. D., Rozhan, M. R., Shamsul, A. S., \& Zasmani, S. (2009). Psychosocial Factors Influencing Truancy in High Risk Secondary Schools in Kuala Lumpur. Malaysian Journal of Psychiatry, 18.

Pengpid, S., \& Peltzer, K. (2013). Bullying and Its Associated Factors among School-Aged Adolescents in Thailand. The 
Scientific World Journal, 2013, Article ID: 254083. http://dx.doi.org/10.1155/2013/254083

Seter, S., Adamson, S. M., \& Emmanuel, R. (2007). Prevalence and Correlates of Truancy among Adolescents in Swaziland: Findings from the Global School-Based Health Survey. Child and Adolescent Psychiatry and Mental Health, 1, 15. http://dx.doi.org/10.1186/1753-2000-1-15

Shah, S. A., Abdullah, A., Aizuddin, A. N. et al. (2012). Psycho-Behavioural Factors Contributing to Truancy among Malay Secondary School Students in Malaysia. ASEAN Journal of Psychiatry, 13, 128-137.

Vaughn, M. G., Maynard, B. R., Salas-Wright, C. P., Perron, B. E., \& Abdon, A. (2013). Prevalence and Correlates of Truancy in the US: Results from a National Sample. Journal of Adolescence, 36, 767-776. http://dx.doi.org/10.1016/j.adolescence.2013.03.015

WHO (2007). Indonesia 2007 GSHS Fact Sheet. www.who.int/chp/gshs/2007 Indonesia fact sheet.pdf

WHO (2008). Thailand 2008 GSHS Fact Sheet. www.who.int/chp/gshs/2008_Thailand_fact_sheet.pdf

Zhang, D., Willson, V., Katsiyannis, A., Barrett, D., Ju, S., \& Wu, J.-Y. (2010). Truancy Offenders in the Juvenile Justice System: A Multicohort Study. Behavioral Disorder, 35, 229-242.

\section{Submit or recommend next manuscript to SCIRP and we will provide best service for you:}

Accepting pre-submission inquiries through Email, Facebook, Linkedin, Twitter, etc A wide selection of journals (inclusive of 9 subjects, more than 200 journals)

Providing a 24-hour high-quality service

User-friendly online submission system

Fair and swift peer-review system

Efficient typesetting and proofreading procedure

Display of the result of downloads and visits, as well as the number of cited articles

Maximum dissemination of your research work

Submit your manuscript at: http://papersubmission.scirp.org/ 